\title{
Identification of a functional glucocorticoid response element in the promoter of the cyclin-dependent kinase inhibitor $\mathrm{p} 57^{\mathrm{Kip} 2}$
}

\author{
K Alheim ${ }^{1,2}$, J Corness ${ }^{1}$, M K R Samuelsson ${ }^{1}$, L-G Bladh'1, T Murata1, T Nilsson ${ }^{1}$ \\ and S Okret ${ }^{1}$ \\ ${ }^{1}$ Department of Medical Nutrition, Karolinska Institutet, Huddinge University Hospital, Novum S-141 86 Huddinge, Sweden \\ ${ }^{2}$ Södertörns Högskola (University College), S-141 04 Huddinge, Sweden \\ (Requests for offprints should be addressed to S Okret; Email: sam.okret@mednut.ki.se) \\ (J Corness is now at Laboratoire de Génétique Moléculaire de la Neurotransmission et des Processus Neurodégénératifs (LGN), Centre National de \\ la Recherche Scientifique (CNRS), Bâtiment C.E.R.V.I., Hôpital de la Pitié Salpêtrière, 83 Boulevard de l'Hôpital, 75013 Paris, France)
}

\begin{abstract}
Glucocorticoids are known regulators of the cell cycle, normally exerting an anti-proliferative effect. We have previously shown that glucocorticoids stimulate expression of $\mathrm{p} 57^{\mathrm{Kip} 2}$, a member of the Cip/Kip family of cyclin-dependent kinase inhibitors which, in some cell types, may account for the anti-proliferative responses seen after glucocorticoid treatment. The induction of $\mathrm{p} 57^{\mathrm{Kip} 2}$ involves primary transcriptional effects where no de novo protein synthesis is necessary, suggesting a direct interaction of the glucocorticoid receptor with the $p 57^{\text {Kip2 }}$ gene. In this study we have identified a functional glucocorticoid response element (GRE), located 5 kilo bases $(\mathrm{kb})$ upstream of the transcription start site in the human $\mathrm{p} 57^{\mathrm{Kip} 2}$ promoter. This GRE was functional also when isolated, suggesting a direct transcriptional effect of the glucocorticoid receptor. Furthermore, mutation of this GRE abolished glucocorticoid induction of the reporter gene, whereas mutation of a nearby Sp1 site did not. Using electrophoretic mobility shift assays, we have shown that the $-5 \mathrm{~kb} p 57^{\text {Kip2 }}$ promoter GRE was able to compete with a well-known GRE for glucocorticoid receptor binding. Sequence comparisons with the mouse genome showed that this GRE is highly conserved, further strengthening the biological importance of this site. All these data emphasize the involvement of this GRE in the glucocorticoid-mediated induction of $\mathrm{p} 57^{\mathrm{Kip} 2}$ expression.
\end{abstract}

Journal of Molecular Endocrinology (2003) 30, 359-368

\section{Introduction}

Glucocorticoids are steroid hormones, produced in the adrenal cortex, that play important roles in metabolism, immune responses, cell proliferation and differentiation. They exert their function by binding to the intracellular glucocorticoid receptor (GR), which is a ligand-activated transcription factor. When bound to its ligand, GR homodimerizes and translocates to the nucleus where it interacts with specific DNA sequences, known as glucocorticoid response elements (GREs), in target genes. Thereby, transcription from these genes is increased (Beato et al. 1995). The GREs are normally palindromic, with two hexameric half- sites separated by three nucleotides, the perfect palindromic GRE reading 5'-AGAACAnnnTG TTCT-3'. However, a consensus GRE derived from comparison of functional GREs in target genes reads 5'-GGTACAnnnTGTTCT-3' (Zilliacus et al. 1995). In addition, more recent results have demonstrated that the GR can stimulate the expression of target genes without directly contacting a GRE (Teurich \& Angel 1995, Stocklin et al. 1996, Rüdiger et al. 2002, Subramaniam et al. 2003). This also seems to be the case for other nuclear receptors, e.g. the progesterone receptor, which has been shown to transduce an effect through $\mathrm{Sp} 1$ in the p21 ${ }^{\text {Cip1 }}$ gene (Owen et al. 1998). 
Glucocorticoids (GC) inhibit proliferation in many tissues and cells, including those of lymphoid, fibroblastic, epithelial, and bone origin. This anti-proliferative effect is normally represented by arresting the cells in the $\mathrm{G}_{1}$-phase of the cell cycle (Sanchez et al. 1993, Frost et al. 1994, Rhee et al. 1995, Corroyer et al. 1997, Rogatsky et al. 1997). Progression through $\mathrm{G}_{1}$ - and entry into S-phase is positively regulated by the activation of cyclindependent kinase 2 (GDK2), which is complexed with cyclin A or cyclin E (Sherr 1993). However, proteins that directly interact with the $\mathrm{CDK}$-cyclin complexes, the so-called CDK inhibitors, can inhibit the activity of CDK2. The family of CDK inhibitors that inhibits CDK2 activity, the Cip/Kip family, consists of three members: p2 ${ }^{\mathrm{Cip} 1}, \mathrm{p} 27^{\mathrm{Kip} 1}$ and $\mathrm{p} 57^{\text {Kip2 }}$ (Sherr \& Roberts 1999). We have previously identified the cyclin-dependent kinase inhibitor $\mathrm{p} 57^{\mathrm{Kip} 2}$ as a glucocorticoid-induced protein that inhibits cell proliferation in HeLa cells by accumulating the cells in the $G_{1}$-phase (Samuelsson et al. 1999). This increase in p57 Kip2 protein expression correlates with an induced expression of the $\mathrm{p} 57^{\mathrm{Kip} 2} \mathrm{mRNA}$ which, at least in part, implicates transcriptional regulation. Furthermore, the response is direct as no de novo protein synthesis is required, suggesting a direct interaction of the GR with regulatory elements in the $\mathrm{p} 57^{\mathrm{Kip} 2}$ gene.

The aim of the present study was to identify putative GREs in the human $\mathrm{p} 57^{\mathrm{Kip} 2}$ promoter responsible for this transcriptional induction. For this purpose we used the human $\mathrm{p} 57^{\mathrm{Kip} 2}$ promoter coupled to a luciferase reporter gene to perform transient transfections. The results demonstrated that the induction of $\mathrm{p} 57^{\mathrm{Kip} 2}$ by glucocorticoids is mediated by a GRE, located 5 kilo bases (kb) upstream of the transcription start site, an effect that is GR dependent. Moreover, glucocorticoid responsiveness was lost by mutating this GRE. Electrophoretic mobility shift assays further confirmed binding of GR to this GRE.

\section{Materials and methods}

\section{Promoter constructs}

A $40 \mathrm{~kb}$ cosmid containing the human p57 Kip2 promoter was a kind gift from Dr Laura Hink Reid (University of North Carolina, USA) (Reid et al. 1996). The $\mathrm{p} 57^{\mathrm{Kip} 2}$ promoter fragments were cloned into the polylinker of a luciferase-based reporter vector, pGL3-Basic vector (Promega), by restriction enzyme digestion and ligation. The different promoter constructs include different lengths of the human $\mathrm{p} 57^{\mathrm{Kip} 2}$ promoter (numbers refer to location corresponding to transcriptional start site $=+1$ ): Hinc 6.3: -6339 to $+14 ; \mathrm{Kpn} 4 \cdot 2$ : -4236 to +14 ; Sac $4 \cdot 0$ : -3987 to +14 ; Sca $3 \cdot 1$ : -3107 to $+14 ; \operatorname{Kpn} 2 \cdot 2$ : -2201 to +14 ; Hinc $1 \cdot 6$ : -1552 to $+14 ; \operatorname{Bgl} 1 \cdot 0$ : -1025 to +14 ; Min: -110 to +14 ; K-S/min: -5461 to $-5015+-110$ to +14 ; $\mathrm{WT} / \mathrm{min}:-5082$ to $-5042+-110$ to +14 .

In the $\mathrm{WT} / \mathrm{min}$ plasmid, the sequence -5082 to -5042 was synthesized and ligated into the Min plasmid. The TAT-GRE plasmid was obtained by ligation of a pair of synthetic oligonucleotides containing a GRE from the tyrosine amino transferase (TAT) promoter (Jantzen et al. 1987) into the Min plasmid. The sequence of the oligonucleotides used was (with the GRE underlined; dotted underlined represents not sequence specific)

TAT-GRE forward oligo: 5'-GTAGGATTAC TAGAAGATGGTGTAGAGTGGACA-3'

TAT-GRE reverse oligo: 5'-CGGGTGTGGAC TGTAGAGGATGTTCTAGTAATG-3'

\section{Plasmid mutations}

Plasmids including mutations of the putative GRE or Spl binding site were obtained by site-directed mutagenesis (Borns et al. 2000). The same mutations were obtained in both the short $40 \mathrm{bp}$ insert (WT/min plasmid) and in the long $446 \mathrm{bp}$ insert (K-S/min plasmid). Hence, four different mutant versions of the plasmids were obtained. Mutated GRE in WT/min vector (GREmut/WT); mutated Spl site in WT/min (Splmut/WT); mutated GRE in K-S/min (GREmut/KSm); Spl site mutation in $\mathrm{K}-\mathrm{S} / \mathrm{min}$ (Splmut/KSm). In addition, two point mutations were made in the $\mathrm{WT} / \mathrm{min}$ to mimic the mouse sequence of the $-5 \mathrm{~kb}$ GRE (mouseGRE).

For the site-directed mutations, $50 \mu \mathrm{l}$ reaction containing 5-25 $\mathrm{ng} \mathrm{WT} / \mathrm{min}$ or $\mathrm{K}-\mathrm{S} / \mathrm{min}$ plasmid, 2.5 U PfuTurbo DNA polymerase (Stratagene), $5 \mu \mathrm{l}$ $10 \times$ reaction buffer (Stratagene), $0.2 \mathrm{mM}$ of each $\operatorname{dNTP}(\mathrm{A}, \mathrm{C}, \mathrm{G}, \mathrm{T})$, and $125 \mathrm{ng}$ of each (forward and reverse) mutation primer was used. The mutation primers were ordered from and synthesized by 
Thermo Hybaid, Interactiva Division (Thermo Hybaid GmbH, Ulm, Germany).

The sequence of the primers used was: GRE mutation forward primer: 5'-GCAGCTGCCGC AAGACAAGCTTACGCTGGGGGGGGGGGG3', GRE mutation reverse primer: 5'-GCGCGG CGCGGCAGGGTAAGCTTGTCTTGGGGGA GCTGG-3

Spl mutation forward primer: 5'-GAACAGCG TGTCGTGGGAAGGTTGACGAGCGTTGAG CTCTTACG-3', Spl mutation reverse primer: 5'-CGTAAGAGCTCAAGGGTCGTCAAGCTT CGCAGGACAGGCTGTTC-3'. Mouse GRE forward primer: 5'-GCGCGAAGAACAGGCGGT CCT ${ }^{\mathrm{G}}$ GGGGGCGGGGCGAGCG-3', mouse $\overline{\text { GRE }}$ reverse primer: 5'-GGCTCGCGCGGCG CGC - AGGACGGGCTGTTCTTGGGGG-3'.

Affected transcription factor/receptor binding elements are underlined, mutations are shown in bold, and eliminated bases are shown as strikethrough superscript.

The $50 \mu \mathrm{l}$ reaction was overlaid with $30 \mu \mathrm{l}$ mineral oil (Sigma) before it was put in a Perkin-Elmer Gene Amp 9600 thermocycler for PGR. An initial $30 \mathrm{~s} 94^{\circ} \mathrm{C}$ heat pulse was followed by 16 cycles of $95^{\circ} \mathrm{C}$ for $30 \mathrm{~s}, 55^{\circ} \mathrm{C}$ for $1 \mathrm{~min}$ and $68{ }^{\circ} \mathrm{C}$ for $10 / 11 \mathrm{~min}(10 \mathrm{~min}$ for $\mathrm{WT} / \mathrm{min}$ plasmid and $11 \mathrm{~min}$ for $\mathrm{K}-\mathrm{S} / \mathrm{min}$ plasmid respectively), after which samples were chilled to $4{ }^{\circ} \mathrm{C}$. The PCR products were cleaved with $10 \mathrm{U}$ DpnI enzyme (Sigma) in $37^{\circ} \mathrm{C}$ for $1 \mathrm{~h}$. The DpnI enzyme cleaves only methylated DNA, hence only the parental template strand was cleaved, whereas the mutated synthesized DNA could be used for transformation. DH5 $\alpha$ competent bacteria (Life Technologies, Paisley, UK) were transformed with the mutated plasmids according to the manufacturer's instructions. Plasmids were prepared using the Qiagen Plasmid Maxi kit (Qiagen) according to the manufacturer's instructions. Plasmids were sequenced (Cybergene, Huddinge, Sweden) to assure correct mutations were obtained.

\section{Cell culture}

A-549 cells are of human epithelial lung carcinoma origin (Lieber et al. 1976) and 293 cells are epithelial cells of human embryonic kidney origin (Graham et al. 1977). The 293 cells used in this study are a Flp-In cell line (Invitrogen). A-549 cells and 293 cells were grown at $37^{\circ} \mathrm{C}$ in $5 \% \mathrm{CO}_{2}$ in a medium containing 45\% $\quad$ F12 (HAM) (Life Technologies), 45\% DMEM (Life Technologies), 9\% fetal calf serum (Integro b.v., Zaandam, Holland), penicillin/streptomycin $10 \mathrm{IU} / \mathrm{ml}$ and $100 \mu \mathrm{g} / \mathrm{ml}$ respectively (Life Technologies), and $2 \mathrm{mM}$ L-glutamine (Life Technologies). The Flp-In293 cells were grown in the presence of $100 \mu \mathrm{g}$ Zeocin/ml (Invitrogen); stably transfected Flp-In293 cells were grown in the presence of $100 \mu \mathrm{g}$ Hygromycin/ml (Invitrogen). Cells were split 1:5 1:10, 2-3 times per week.

\section{Stable transfections}

The Flp-In-293 cells were stably transfected with pcDNA5/FRT expression vector containing the rat glucocorticoid receptor gene (Godowski et al. 1988) according to instructions from the manufacturer. Clones expressing GR were selected and maintained in Hygromycin-containing medium.

\section{Transient transfections}

Lipofectin reagent (Gibco BRL/Invitrogen) was used, according to the manufacturer's instructions, to transfect A-549 and 293 cells with the different plasmids. As an internal control, pRL-SV40 vector (Promega), containing the SV40 early enhancer/ promoter region, providing a strong constitutive expression of Renilla luciferase, was used.

The day before the experiment a total of 60000 A-549 cells/well were seeded out in 6-well culture dishes. An equimolar amount of the plasmid tested (corresponding to $1 \mu \mathrm{g}$ Min plasmid), together with $25 \mathrm{ng}$ pRL-SV40 vector (as an internal control), were used for each $9 \cdot 5-\mathrm{cm}^{2}$ well. Following transfection, the cells were treated with $1 \mu \mathrm{M}$ (or $100 \mathrm{nM}$ for Fig. 3B) dexamethasone (Sigma) (or $0 \cdot 01 \%$ ethanol as control) for $22-24 \mathrm{~h}$ before harvesting.

The day before the experiment, 293 cells were seeded out at 40000 cells/well in 24-well culture dishes. Two hundred nanograms Min, WT/min or GREmut/WT plasmid, together with $5 \mathrm{ng}$ pRLSV40 vector were used for each $2-\mathrm{cm}^{2}$ well. Following transfection, the cells were left to recover for $18-20 \mathrm{~h}$, and subsequently treated with $100 \mathrm{nM}$ dexamethasone (Sigma) (or 0.001\% ethanol as control) and/or with $1 \mu \mathrm{M}$ RU-486 (Mifepristone, Sigma) (or $0.01 \%$ ethanol as control) for $24 \mathrm{~h}$ 
before harvesting. All treatments were carried out in triplicate.

\section{Dual-Luciferase assay}

The Dual-Luciferase Reporter assay system (Promega) was used according to the manufacturer's instructions. All samples were measured consecutively for firefly luciferase and Renilla luciferase expression within the same plate. The individual firefly luciferase values (promoter activity) were then divided by the Renilla values (internal control) thus correcting for differences in transfection efficiency. The averages of these values (in triplicate) were used to calculate the dexamethasone inducibility (fold induction) of reporter expression.

\section{Electrophoretic mobility shift assay}

For the electrophoretic mobility shift assay (EMSA), the GRE from the tyrosine aminotransferase (TAT) gene (Heck et al. 1994) was end-labeled by $\mathrm{T} 4$ polynucleotide kinase using $\left[\gamma_{-}{ }^{32} \mathrm{P}\right] \quad(3000 \mathrm{Ci} / \mathrm{mmol}$, Amersham Pharmacia Biotec) (GREtat probe). DNA binding reactions of $20 \mu \mathrm{l}$ were carried out in a buffer containing $20 \mathrm{mM}$ Tris $-\mathrm{HCl} \mathrm{pH} 8 \cdot 0,10 \%$ (w/v) glycerol, $1 \mathrm{mM}$ EDTA, $1 \mathrm{mM}$ dithiothreitol, $2 \mu \mathrm{g}$ poly (dI-dC) (Amersham Pharmacia Biotec), $75 \mathrm{mM}$ $\mathrm{KCl}, 3 \%$ bovine serum albumin, 0.05-0.2 ng radiolabeled GRE and $10 \mu \mathrm{g}$ extract from bacculovirus-expressed full length human GR (kindly provided by Dr Stefan Nilsson, Karo-Bio AB, Sweden) (Dahlman-Wright et al. 1993). Binding reactions were performed at room temperature for $30 \mathrm{~min}$. When indicated, a 200-molar excess of unlabeled GREtat or the p57 ${ }^{\text {Kip2 }}$-GRE (or mutated versions of this) was included in the binding reaction. Free and bound DNA were separated on $4 \%$ polyacrylamide gel, which was run at a constant voltage of $200 \mathrm{~V}$ in $22 \mathrm{mM}$ Tris-borate, $0.5 \mathrm{mM}$ EDTA.

The probes used for EMSA were double stranded DNA (Thermo Hybaid $\mathrm{GmbH}$ ) with the upper strand sequence (GRE underlined): GREtat: 5'-ATTACTAGAAGATGGTGTAGAGTGGAC3'; human p57 Kip2 GRE (GRE-Sp1): 5'-GCAGC TGGCGCAAGAACAGCGTGTCATGGGGGG CGGGGGGAGCGTTGAGCTCGGGGAAC-3'; mutated p5 $7^{\text {Kip2 }}$ GRE (GREmut-Sp1): 5'GCAGC
TGCCCCAAGACAAGCTTACCCTGGGGGG CGGGGC- $3^{\prime}$; p57 5 Kip $^{2} \mathrm{GRE}$ with mutated Spl (GRE-Splmut): 5'-GCGCCAAGAACAGCGTGT CGTGGGAAGGTTGACGAGCGTTG-3'; Spl: 5'-ATTGGATGGGGGGGGGGGGAGG-3'; AP-1: 5'-CTAGGTGTCTGACTCATGCTT-3'; mousep57 ${ }^{\text {Kip2 }}$ GRE: 5'-GCGCCAAGAACAGCCGGTC CTGGGGGCGGGGGGAGGG-3'.

\section{Western blot analysis}

A-549 cells were seeded at subconfluent levels in $55-\mathrm{cm}^{2}$ plates the day before treatment. Cells were treated with $100 \mathrm{nM}$ dexamethasone for 2, 4, 6, 8 or $24 \mathrm{~h}$ or with normal growth medium, supplemented with $0.001 \%$ ethanol, as a vehicle control.

Whole cell extracts for Western blot analysis were prepared by lysing the cells in ice-cold Nonidet P-40 (NP-40) buffer (0.5\% NP-40, $50 \mathrm{mM}$ Tris-HCl pH 8.0, $150 \mathrm{mM} \mathrm{NaCl}, 5 \mathrm{mM}$ EDTA) for $10 \mathrm{~min}$, after which cell debris was removed by centrifugation at $14000 \times \boldsymbol{g}$ for $10 \mathrm{~min}$ at $4{ }^{\circ} \mathrm{C}$. An equal volume of $2 \times \mathrm{SDS}$ gel-loading buffer was then added to the supernatant and the samples were boiled for $2 \mathrm{~min}$. Protein concentration in cell extracts was quantified spectrophotometrically prior to addition of the loading buffer with the Bio-Rad protein assay kit, according to the instructions of the manufacturer (Bio-Rad, Hercules, CA, USA). Protein $(20 \mu \mathrm{g})$ from each whole cell extract was electrophoretically separated on a 9\% SDS-polyacrylamide gel and electroblotted onto a Hybond G-extra membrane (Amersham Life Sciences, UK). For protein detection, the immunoblots were probed with a rabbit IgG polyclonal anti-p57 ${ }^{\mathrm{Kip} 2}$ antibody (C-20, Santa Cruz Biotechnology, Inc., Santa Cruz, CA, USA) (1:100). As secondary antibody, a horseradish-peroxidase-conjugated anti-rabbit antibody (Amersham Life Sciences, UK) (1:3000) was used. The membranes were then subjected to enhanced chemiluminescence (Amersham Life Sciences, UK) and autoradiography, according to the instructions of the manufacturer. To check for equal loading and transfer, the membranes were stained with Ponceau red (Sigma) prior to addition of antibody, as well as reprobed with a mouse IgG monoclonal anti- $\beta$-tubulin antibody (N357, Amersham Life Sciences, UK) (1:3000). As 
secondary antibody, a horseradish-peroxidaseconjugated anti-mouse antibody (Amersham Life Sciences, UK) (1:3000) was used.

\section{Statistics}

$P$ values for comparison of samples were obtained by using the paired $t$-test with two-tailed distribution using the Microsoft Excel program.

\section{Results}

\section{Identification of a functional glucocorticoid response element in the human $\mathrm{p} 57^{\mathrm{Kip} 2}$ promoter}

To find a functional GRE in the $\mathrm{p} 57^{\mathrm{Kip} 2}$ gene, the human $\mathrm{p} 57^{\text {Kip2 }}$ promoter was analyzed using fragments of the promoter, which were inserted into the pGL3-Basic luciferase reporter vector. The lengths of the promoter fragments used ranged from just over 100 bases to approximately $6 \cdot 3 \mathrm{~kb}$ long. The resulting plasmids were transfected into A-549 cells. By Western blotting technique, A-549 cells were found to be inducible for expression of endogenous $\mathrm{p} 57^{\mathrm{Kip} 2}$, in a time-dependent manner, after dexamethasone exposure (Fig. 1A, upper panel), showing that these cells present a good model system for studying the underlying mechanisms for this induction. Equal loading and transfer of protein was confirmed by using a $\beta$-tubulin antibody (Fig. 1A, lower panel).

After transfection with the various $\mathrm{p} 57^{\text {Kip2 }}$ promoter constructs, A-549 cells were treated with dexamethasone, and expression of the luciferase reporter was measured using the Dual-Luciferase Reporter assay (Fig. 1B). Using the differently sized promoter constructs, a $2 \mathrm{~kb}$ long area of interest $(-6.3 \mathrm{~kb}$ to $-4.2 \mathrm{~kb})$, which caused a threefold increase in luciferase expression following dexamethasone administration to the cells, was identified (Fig. 1B). Possible GREs, based on similarity to the consensus sequence, were searched for within this $2 \mathrm{~kb}$ region. A putative GRE was found around $-5 \mathrm{~kb}$, and a $446 \mathrm{bp}$ fragment $(-5461$ to -5015) spanning this GRE was inserted into the pGL3-Basic vector upstream of the minimal promoter (ranging from $-100 \mathrm{bp}$ to +14 ) (K-S/ min). This short promoter stretch was able to induce the luciferase expression three- to fivefold, when stimulated by the glucocorticoid agonist dexamethasone (see Figs $1 \mathrm{~B}$ and 2A). To further pinpoint the GRE, an even shorter (40 bp)
A

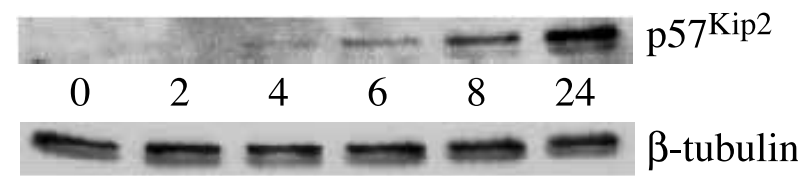

B

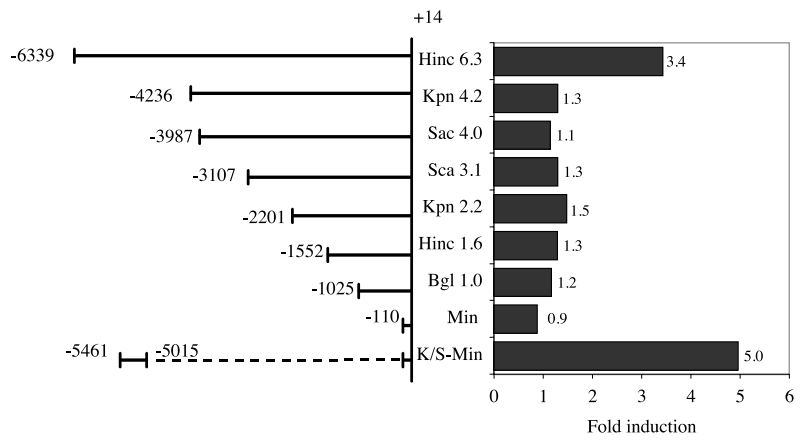

Figure 1 (A) Western blot of $p 57^{\text {Kip2 }}$ expression in A-549 cells: expression of $p 57^{\text {Kip2 }}$ in A-549 cells (upper panel) following $100 \mathrm{nM}$ dexamethasone treatment for 0 to $24 \mathrm{~h}$ (time indicated in $\mathrm{h}$ ). As a control for equal amount of protein loading and transfer, the filter was reprobed with an antibody against $\beta$-tubulin (lower panel). (B) Dexamethasone-induced expression of luciferase reporter gene with different $\mathrm{p} 57^{\mathrm{Kip} 2}$ promoter constructs. The left diagram shows schematically the different promoter constructs used (numbers indicating base pairs from transcription start site). The right diagram shows the induction of luciferase reporter activity after dexamethasone treatment $(1 \mu \mathrm{M}, 24 \mathrm{~h})$, when the respective construct is analyzed (numbers indicating fold induction). One representative experiment, carried out in triplicate, is shown.

synthetic fragment of the $\mathrm{p} 57^{\mathrm{Kip} 2}$ promoter $(-5082$ to -5042$)$, spanning the putative $-5 \mathrm{~kb}$ p $57^{\text {Kip2 }}$ GRE, was analyzed (WT/min). Indeed, this $40 \mathrm{bp}$ sequence was sufficient to drive the glucocorticoidinduced expression of the reporter (Fig. 2A). Mutation of this putative $\mathrm{p} 57^{\mathrm{Kip} 2} \mathrm{GRE}$ resulted in loss of its ability to induce luciferase expression following dexamethasone treatment, in both the 446 bp fragment (GREmut/KSm) and the short 40 bp sequence (GREmut/WT) (Fig. 2A).

When studying the sequence surrounding the core GRE, a putative Spl binding site was found to be located immediately downstream of the GRE. To investigate possible synergistic effects between GR and Spl, the Spl site was mutated, in isolation, in both the short (Splmut/WT) as well as in the longer $446 \mathrm{bp} \mathrm{K-S/min} \mathrm{fragment} \mathrm{(Splmut/KSm).}$ Mutations of the putative Spl binding site did not impair the inducibility by glucocorticoids, but rather enhanced it (Fig. 2A). 
A

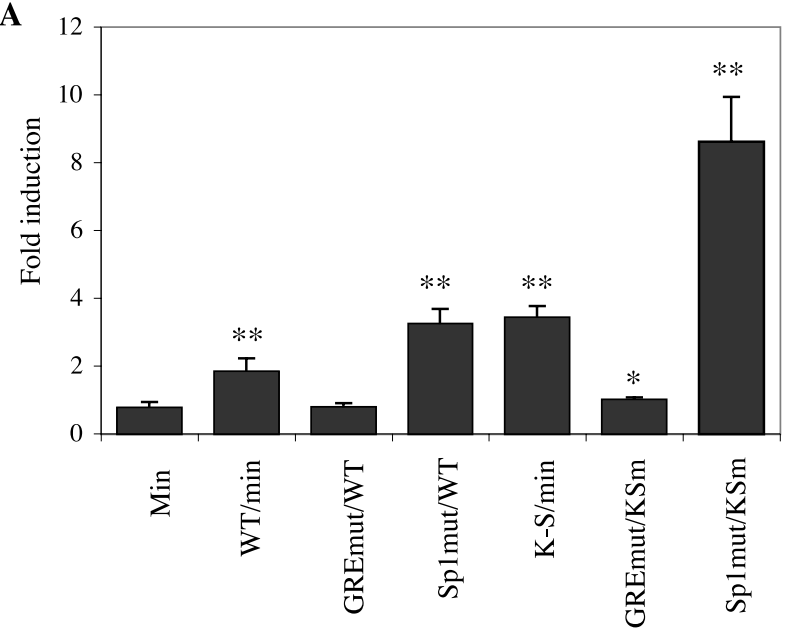

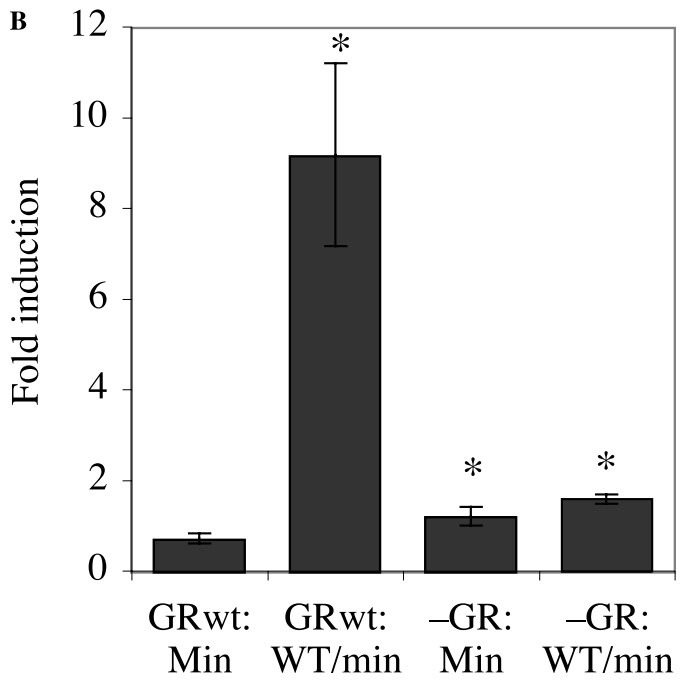

C

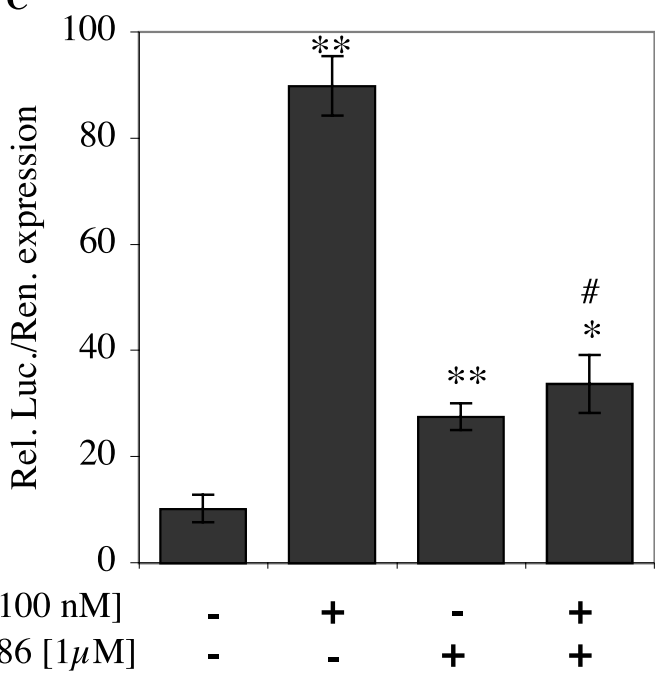

Figure 2 Expression of luciferase reporter is affected by mutations in the p57 Kip2 GRE fragment and is dependent on GR. (A) Mutations in the $\mathrm{p} 57^{\mathrm{Kip} 2} \mathrm{GRE}$ cause alterations in the dexamethasone-induced luciferase reporter expression. A-549 cells were transfected with the $\mathrm{p} 57^{\mathrm{Kip} 2}$ promoter constructs as indicated, and thereafter treated with $1 \mu \mathrm{M}$ dexamethasone for $24 \mathrm{~h}$. WT/min is the 40 bases long sequence, surrounding and including the p57 Kip2 GRE, inserted upstream of the Min promoter. GREmut/WT is the WT/min promoter with the GRE mutated.

Sp1mut/WT is the WT/min promoter with the Sp1 site mutated. $\mathrm{K}-\mathrm{S} / \mathrm{min}$ is the 446 base pair long promoter, inserted upstream of the Min promoter. GREmut/KSm is the K-S/min construct with the GRE mutated. Sp1mut/KSm is the $\mathrm{K}-\mathrm{S} / \mathrm{min}$ construct with the Sp1 site mutated. Results are shown as fold induction of dexamethasone-treated vs control. The mean of four experiments \pm standard deviation is shown. Student's $t$-test is used to calculate the statistical difference of fold induction compared with the Min reporter. ${ }^{\star} P<0.05,{ }^{* \star} P<0 \cdot 01$. (B) GR-dependent reporter expression. GC-mediated induction of luciferase expression in 293 cells without GR (-GR:) or stably transfected with GR (GRwt:) After transfection with Min or WT/min plasmids cells were treated with dexamethasone (100 nM) for $24 \mathrm{~h}$. Results are shown as fold induction of dexamethasone-treated vs control. The mean of three experiments \pm standard deviation is shown. Student's $t$-test is used to calculate the statistical difference of fold induction compared with GRwt: Min. ${ }^{\star} P<0.05$. (C) Effects of glucocorticoid agonist and antagonist on reporter expression. Luciferase expression in GR-expressing 293 cells, after transient transfection with WT/min plasmid and treatment for $24 \mathrm{~h}$ with dexamethasone (Dex, $100 \mathrm{nM})$ and/or RU-486 $(1 \mu \mathrm{M})$ is shown. Results are shown as the relative expression of luciferase (firefly/Renilla (Ren.)). The mean of three experiments \pm standard deviation is shown. Student's $t$-test is used to calculate statistical difference. ${ }^{*} P<0.01$ vs non-treated, ${ }^{\star \star} P<0.001$ vs non-treated, $\# P<0.01$ vs Dex-treated. 

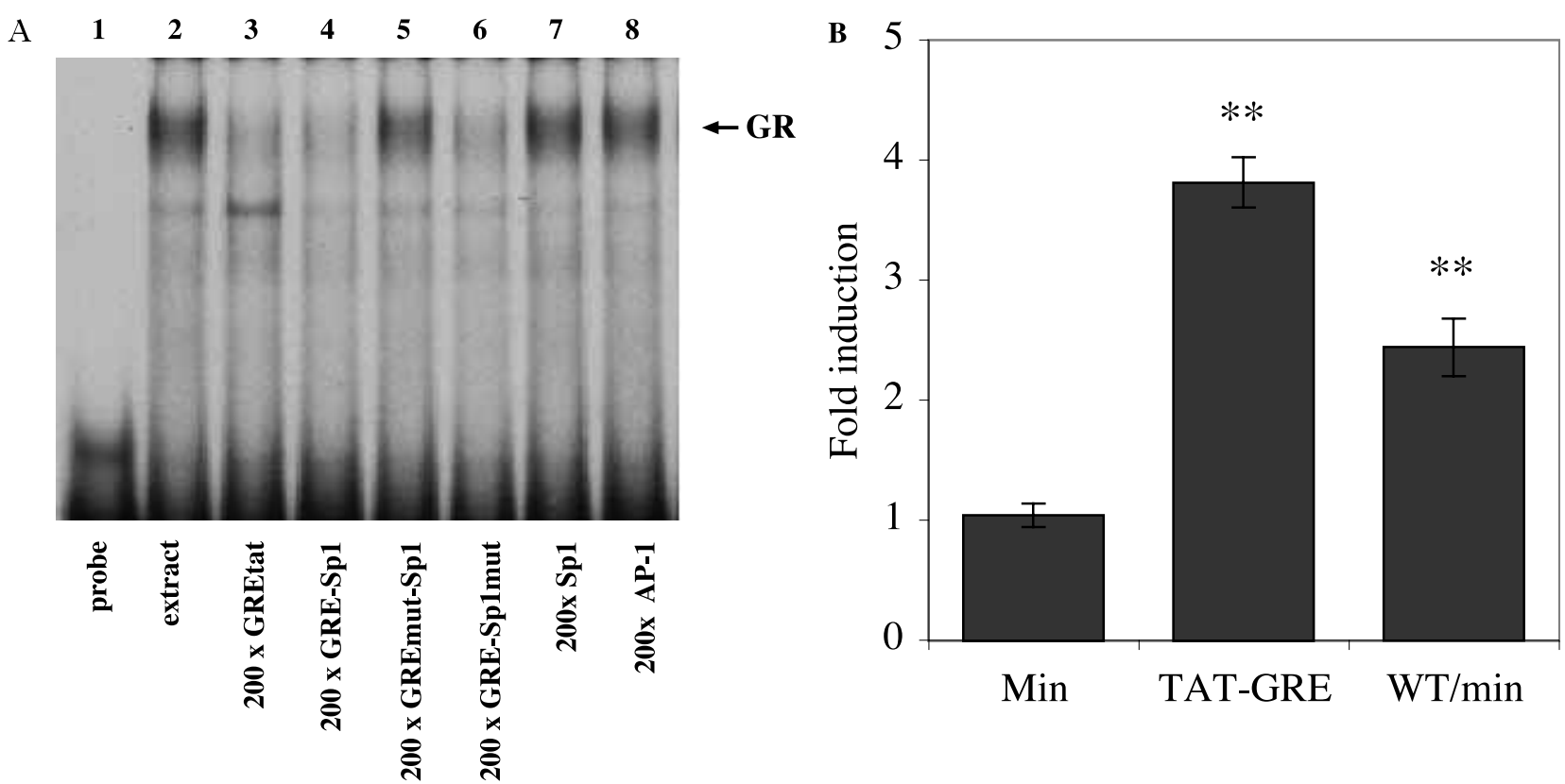

Figure $3(\mathrm{~A})$ EMSA showing the ability of $p 57^{\mathrm{Kip} 2}$ GRE to compete for bacculovirus-expressed GR binding to the GREtat. Lane 1 (probe) is free probe. Bacculovirus-expressed full-length GR (extract) is present in lanes 2-8. In lanes 3-8 the interaction of the GR with the ${ }^{32} \mathrm{P}$-labeled-GREtat probe is challenged by a 200 -fold excess of cold probe (GREtat, GRE-Sp1, GREmut-Sp1, GRE-Sp1mut, Sp1, and AP-1). One representative experiment out of four is shown. (B) Comparison of the inducibility of reporter gene via the $\mathrm{p} 57^{\mathrm{kip} 2} \mathrm{GRE}$ and a classical GRE: expression of luciferase reporter gene under the control of a single GRE from the TAT-promoter (TAT-GRE) compared with a single GRE from the p57 kip2 promoter (WT/min). A-549 cells were transfected with the promoter constructs indicated, and thereafter treated with $100 \mathrm{nM}$ dexamethasone for $24 \mathrm{~h}$. Results are shown as fold induction of dexamethasone-treated vs control. The mean of three experiments \pm standard deviation is shown. Student's $t$-test is used to calculate the statistical difference of fold induction compared with the Min reporter. ${ }^{\star \star} P<0.01$.

The analyses of luciferase expression, using the promoter fragments of the human $\mathrm{p} 57^{\mathrm{Kip} 2}$ gene and mutations of the putative GRE, clearly showed that the GRE located -5076 to -5062 in the human $\mathrm{p} 57^{\mathrm{Kip} 2}$ promoter was involved in the inducibility by glucocorticoids (Fig. 2A).

To verify that the effect found was dependent on the GR, 293 cells, which lack endogenous GR (-GR), were compared with stably transfected GR-expressing 293 cells (GRwt). After transfection with the Min and $\mathrm{WT} / \mathrm{min}$ plasmids, the dexamethasone-induced expressions of the reporter gene clearly demonstrate that this effect is GR-dependent (Fig. 2B). In addition, the dexamethasone-induced luciferase reporter gene expression, under the control of the $\mathrm{p} 57^{\mathrm{Kip} 2} \mathrm{GRE}$ in these cells, was significantly attenuated by the glucocorticoid antagonist RU-486 (Fig. 2C). Although mainly working as an antagonist, RU-486 is known to have a low agonistic activity on GR (Schulz et al. 2002), which is seen also in this experiment. Using the construct with a mutated p57 ${ }^{\text {Kip2 }}$ GRE (GREmut), neither dexamethasone nor RU-486 could induce the expression of the reporter gene (data not shown).

\section{Analysis of GR interaction with the $\mathrm{p} 57^{\mathrm{Kip} 2}$ GRE by EMSA}

In order to investigate the ability of the $-5 \mathrm{~kb}$ putative $\mathrm{p} 57^{\mathrm{Kip} 2} \mathrm{GRE}$ to interact with GR, its capacity to compete GR binding to a well-known GRE (GRE II) from the tyrosine amino transferase (TAT) promoter (Jantzen et al. 1987) was tested.

Incubation of ${ }^{32} \mathrm{P}$-labeled TAT-GRE (GREtat) with bacculovirus-expressed full length GR resulted in a complex that could be competed by a 200fold excess of unlabeled GREtat as well as the $-5 \mathrm{~kb}$ p5 $7^{\text {Kip2 }}$ GRE (GRE-Spl) (Fig. 3A). However, the probe with the $-5 \mathrm{~kb}$ p $57^{\mathrm{Kip} 2} \mathrm{GRE}$ mutated (GREmut-Spl) could not compete out the 
Table 1 Sequence of the human $\mathrm{p} 57^{\mathrm{Kip} 2} \mathrm{GRE}$ and mutations introduced as well as a comparison with the mouse $\mathrm{p} 57^{\mathrm{kip} 2} \mathrm{GRE}$

\begin{tabular}{|c|c|}
\hline $\begin{array}{l}\text { Human } p 57^{\text {Kip2 }} \\
-5082 \text { to }-5042\end{array}$ & 5'-GCCCCAAGAACAGCCTGTCCTGGGGGGCGGGGCGAGCCTTG-3 \\
\hline GRE mutation & 5'-GCCCCAAGACAAGCITACCCTGGGGGGCGGGGCGAGCCTTG-3 \\
\hline Sp1 mutation & 5'-GCCCCAAGAACAGCCTGTCCTGGGAAGCITGACGAGCCTTG-3' \\
\hline $\begin{array}{l}\text { Mouse p57 }{ }^{\text {Kip2 }} \\
-4028 \text { to }-3989\end{array}$ & 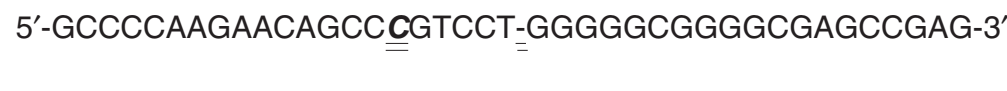 \\
\hline
\end{tabular}

labeled probe, demonstrating the requirement of an intact p57 Kip2 GRE. Mutating the Spl site in the $40 \mathrm{bp}$ fragment containing the p5 $7^{\mathrm{Kip} 2}$ GRE did not affect GR interaction with the labeled probe, as the GRE-Splmut probe was still able to compete out the labeled probe. Non-specific unlabeled oligonucleotides containing a consensus site for Spl or AP-1 binding could not compete out the interaction between the GR and GREtat probe, demonstrating that the GR interaction with p5 $7^{\mathrm{Kip} 2}$ GRE is specific.

To compare the activity of the $-5 \mathrm{~kb}$ p $57^{\mathrm{Kip} 2}$ GRE to the prototype GRE from the TAT gene (GRE II), both were cloned as a single moiety upstream of the $\mathrm{p} 57^{\mathrm{Kip} 2}$ minimal promoter. Both were able significantly to stimulate reporter gene expression after dexamethasone exposure, although the $\mathrm{p} 57^{\mathrm{Kip} 2}$ GRE was slightly less effective (Fig. $3 \mathrm{~B})$.

\section{A conserved and functional GRE is present in the mouse $\mathrm{p} 57^{\mathrm{Kip} 2}$ promoter}

To find evolutional support that the identified GRE in the human $\mathrm{p} 57^{\mathrm{Kip} 2}$ gene is of importance in GC regulation of $\mathrm{p} 57^{\mathrm{Kip} 2}$ expression, a sequence comparison was made with the mouse $\mathrm{p} 57^{\mathrm{Kip} 2}$ promoter. This comparison revealed a very similar GRE present in the mouse p $57^{\text {Kip } 2}$ promoter, only differing in one nucleotide position as compared with the human p57 ${ }^{\mathrm{Kip} 2}$ GRE (position 10 of the 15 bp GRE: $\mathrm{T} \rightarrow \mathrm{C}$ ). Furthermore, the mouse p57 Rip2 promoter contained a one-nucleotide deletion immediately $3^{\prime}$ of the GRE (Table 1). In order to test whether the altered nucleotides had any functional effect on the ability of the mouse p5 $7^{\text {Kip2 }}$ GRE to confer a GG response, the two differences were introduced $(\mathrm{a} T \rightarrow \mathrm{C}$ change in the GRE and an elimination of a $\mathrm{G}$ in the putative $\mathrm{Spl}$ binding site) in the context of the human $\mathrm{p} 57^{\mathrm{K} \text { p2 }}$ GRE. In luciferase reporter expression experiments, it was shown that the mouse GRE is functional, albeit slightly weaker than the corresponding human GRE (Fig. 4). Furthermore, the mouse p5 $7^{\text {Kip2 }}$ GRE was, like the human p57 ${ }^{\text {Kip2 }}$ GRE, able to compete out GR binding to the TAT-GRE probe in the EMSA (data not shown).

\section{Discussion}

The $\mathrm{p} 57^{\mathrm{Kip} 2}$ promoter deletion studies and mutational studies suggest that the GRE located 5076 to 5062 bases upstream of the transcription start site of the human $\mathrm{p} 57^{\mathrm{Kip} 2}$ gene is responsible for the glucocorticoid inducibility of the $\mathrm{p} 57^{\mathrm{Kip} 2}$ gene. This GRE is functional, even as an isolated 40 bp fragment. However, we cannot exclude the possibility that there are other parts of the gene, upstream or downstream of the $6.4 \mathrm{~kb}$ promoter region, that may contribute to the GC regulation of p57 ${ }^{\text {Kip2 }}$ expression. Low reporter gene induction, as compared with protein, may be because of additional post-transcriptional regulation or other regulatory elements. Moreover, a putative GRE downstream of the transcription start site $(+171$ to +185 bp), with similarities to the consensus GRE, had no significant effect on the dexamethasone inducibility (data not shown). Previously, we have shown that the dexamethasone induction of p5 $7^{\text {Kip2 }}$ is transcriptionally regulated (Samuelsson et al. 1999), and we now conclude that this effect is 


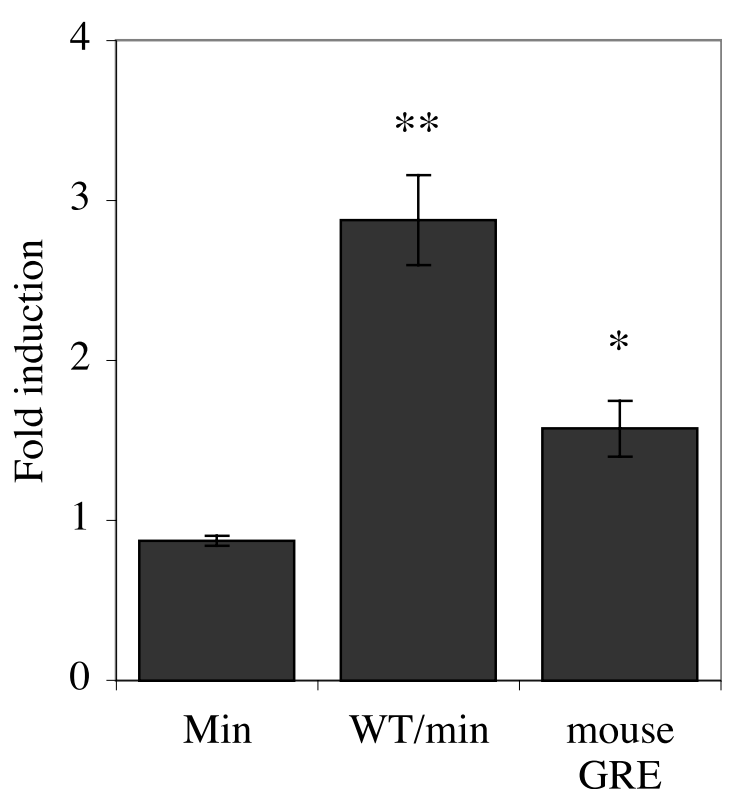

Figure 4 The mouse $\mathrm{p} 57^{\mathrm{Kip} 2} \mathrm{GRE}$ is functionally conserved: dexamethasone-induced expression of luciferase reporter gene, under the control of the mouse p57 ${ }^{\text {Kip2 }}$ GRE (mouse GRE) as compared with the human p57 ${ }^{\mathrm{Kip} 2}$ GRE (WT/min). Results are shown as fold induction of dexamethasone-treated vs control. The mean of three experiments \pm standard deviation is shown. Student's $t$-test is used to calculate the statistical difference of fold induction compared with the Min reporter. ${ }^{\star} P<0.05,{ }^{* *} P<0.01$.

mediated via a direct GRE interaction at the $-5 \mathrm{~kb}$ GRE in the $\mathrm{p} 57^{\mathrm{Kip} 2}$ promoter. Indeed, the clear induction in reporter gene expression seen when treating the cells (transfected with the Hinc 6.3, $\mathrm{K}-\mathrm{S} / \mathrm{min}$ or $\mathrm{WT} / \mathrm{min}$ constructs) with the glucocorticoid agonist, dexamethasone, supports the proposal that glucocorticoid regulation is orchestrated through this GRE. However, posttranscriptional events, e.g. affecting mRNA stability or protein stability, may contribute to the overall expression of $\mathrm{p} 57^{\mathrm{Kip} 2}$ protein. Both $\mathrm{p} 21^{\mathrm{Cip} 1}$ and $\mathrm{p} 27^{\mathrm{Kip} 1}$ have been shown to be upregulated on mRNA or protein levels after glucocorticoid treatment (Corroyer et al. 1997, Ramalingam et al. 1997, Rogatsky et al. 1997). Although transcriptional activation of $\mathrm{p} 21^{\mathrm{Cipl}}$ has been implicated (Ramalingam et al. 1997), the exact mechanisms behind GC regulation of the members of the Cip/Kip family are not fully elucidated. One exception is the GC-mediated induction of $\mathrm{p} 21^{\text {Cip } 1}$ in rat hepatoma cells, where the GR-dependent stimulation of the gene does not involve a consensus GRE, but rather a $\mathrm{C} / \mathrm{EBP} \alpha$-interaction (Cha et al. 1998, Cram et al. 1998). The results presented in this paper identify a functional GRE in the human $\mathrm{p} 57^{\mathrm{Kip} 2}$ promoter, suggesting a classical GC-stimulated pathway.

The involvement of the $-5 \mathrm{~kb}$ GRE in GCorchestrated induction of the $\mathrm{p} 57^{\mathrm{Kip} 2}$ promoter is supported by the observation that interaction between GR and the classical GREtat probe can be competed by an excess of cold GRE-Sp1 oligonucleotide. Furthermore, it is shown that the lack of a glucocorticoid response when the GRE is mutated is due to lack of interaction between the GR and the GRE, as the EMSA showed that the mutated p57 ${ }^{\text {Kip2 }}$ GRE oligonucleotide could not compete out the classical GREtat probe.

Although the p57 $7^{\text {Kip2 }}$ GRE is slightly less efficient than the TAT-GRE in driving the reporter gene expression the results clearly demonstrate that both, significantly and in the same range, can stimulate reporter gene activity after dexamethasone treatment. Moreover, it is shown that the response of the p57 ${ }^{\mathrm{Kip} 2} \mathrm{GRE}$ is dependent on GR and GC agonist, as 293 cells (not expressing GR) transfected with the $\mathrm{p} 57^{\mathrm{Kip} 2}$ promoter construct show no induction of reporter expression after dexamethasone treatment, whereas 293 cells stably expressing GR, transfected with the same p57 Kip2 promoter construct, have a response to dexamethasone similar to A-549 cells that endogenously express GR (Greenberg et al. 2002).

The GRE located $5 \mathrm{~kb}$ upstream of the transcription start site has a putative Spl binding site immediately downstream. Functional interaction between the GC-stimulated and the putative Spl pathways was investigated, since it has previously been shown that the progesterone receptor can regulate the transcription of the p21 ${ }^{\text {CIP1 }}$ gene through binding to Spl (Owen et al. 1998). Complete competition of GRE-GR interaction by excess of the oligo with a mutated Spl site (GRE-Splmut) shows that this putative Spl binding site has no direct effect on GR-DNA binding. However, the induction of reporter protein expression is further enhanced when this putative Spl binding site is mutated (see Fig. 2A), leading us to speculate that $\mathrm{Spl}$ might have a negative effect on transcription by some unknown mechanism, e.g. competition for overlapping binding sites. 
The finding that the mouse GRE (homologous in sequence to the human $-5 \mathrm{~kb}$ GRE, and located $-4 \mathrm{~kb}$ ) is functional in transient transfections, further implies that the glucocorticoid induction of human $\mathrm{p} 57^{\mathrm{Kip} 2}$ is mediated through this GRE. This further suggests that GC regulation of $\mathrm{p} 57^{\mathrm{Kip} 2}$ in vivo is of biological significance. This is presently under investigation.

In conclusion we found that the highly conserved $-5 \mathrm{~kb}$ GRE in the $\mathrm{p} 57^{\mathrm{Kip} 2}$ promoter is involved in the induction of $\mathrm{p} 57^{\mathrm{Kip} 2}$ by dexamethasone and that this induction is orchestrated via a direct GR-GRE interaction.

\section{Acknowledgements}

We wish to thank Ingalill Rafter for valuable technical assistance. This work was supported by grants from the Swedish Cancer Society to S O.

\section{References}

Beato M, Herrlich P \& Schutz G 1995 Steroid hormone receptors: many actors in search of a plot. Cell 83 851-857.

Borns M, Vaillancourt P, Hogrefe H \& Braman J 2000

High-efficiency site-directed mutagenesis of large plasmid vectors. Strategies 13 106-107.

Cha HH, Cram EJ, Wang EC, Huang AJ, Kasler HG \& Firestone GL 1998 Glucocorticoids stimulate p21 gene expression by targeting multiple transcriptional elements within a steroid responsive region of the $\mathrm{p} 21 \mathrm{wafl} / \mathrm{cip} 1$ promoter in rat hepatoma cells. Fournal of Biological Chemistry 273 1998-2007.

Corroyer S, Nabeyrat E \& Clement A 1997 Involvement of the cell cycle inhibitor CIP1/WAF1 in lung alveolar epithelial cell growth arrest induced by glucocorticoids. Endocrinology $1383677-3685$.

Cram EJ, Ramos RA, Wang EC, Cha HH, Nishio Y \& Firestone GL 1998 Role of the GCAAT/enhancer binding protein-alpha transcription factor in the glucocorticoid stimulation of p21 wafl/cipl gene promoter activity in growth-arrested rat hepatoma cells. Fournal of Biological Chemistry 273 2008-2014.

Dahlman-Wright K, Grandien K, Nilsson S, Gustafsson JA \& Carlstedt-Duke J 1993 Protein-protein interactions between the DNA-binding domains of nuclear receptors: influence on DNA binding. Fournal of Steroid Biochemistry and Molecular Biology $\mathbf{4 5}$ 239-250.

Frost GH, Rhee K, Ma T \& Thompson EA 1994 Expression of c-Myc in glucocorticoid-treated fibroblastic cells. Fournal of Steroid Biochemistry and Molecular Biology 50 109-119.

Godowski PJ, Picard D \& Yamamoto KR 1988 Signal transduction and transcriptional regulation by glucocorticoid receptor-LexA fusion proteins. Science 241 812-816.

Graham FL, Smiley J, Russell WC \& Nairn R 1977 Characteristics of a human cell line transformed by DNA from human adenovirus type 5. Fournal of General Virology 36 59-74.

Greenberg AK, Hu J, Basu S, Hay J, Reibman J, Yie TA, Tchou-Wong KM, Rom WN \& Lee TC 2002 Glucocorticoids inhibit lung cancer cell growth through both the extracellular signal-related kinase pathway and cell cycle regulators. American Fournal of Respiratory Cell and Molecular Biology 27 320-328.

Heck S, Kullmann M, Gast A, Ponta H, Rahmsdorf HJ, Herrlich P \& Cato AC 1994 A distinct modulating domain in glucocorticoid receptor monomers in the repression of activity of the transcription factor AP-1. EMBO fournal 13 4087-4095.

Jantzen HM, Strahle U, Gloss B, Stewart F, Schmid W, Boshart M, Miksicek R \& Schutz G 1987 Cooperativity of glucocorticoid response elements located far upstream of the tyrosine aminotransferase gene. Cell 49 29-38.

Lieber M, Smith B, Szakal A, Nelson-Rees W \& Todaro G 1976 A continuous tumor-cell line from a human lung carcinoma with properties of type II alveolar epithelial cells. International fournal of Cancer 17 62-70.

Owen GI, Richer JK, Tung L, Takimoto G \& Horwitz KB 1998 Progesterone regulates transcription of the p21(WAF1) cyclin-dependent kinase inhibitor gene through $\mathrm{Spl}$ and GBP/p300. Fournal of Biological Chemistry 273 10696-10701.

Ramalingam A, Hirai A \& Thompson EA 1997 Glucocorticoid inhibition of fibroblast proliferation and regulation of the cyclin kinase inhibitor p21 Cip1. Molecular Endocrinology 11 577-586.

Reid LH, Crider-Miller SJ, West A, Lee MH, Massague J \& Weissman BE 1996 Genomic organization of the human p57 KIP2 gene and its analysis in the G401 Wilms' tumor assay. Cancer Research 56 1214-1218.

Rhee K, Bresnahan W, Hirai A, Hirai M \& Thompson EA 1995 c-Myc and cyclin D3 (CcnD3) genes are independent targets for glucocorticoid inhibition of lymphoid cell proliferation. Cancer Research 55 4188-4195.

Rogatsky I, Trowbridge JM \& Garabedian MJ 1997 Glucocorticoid receptor-mediated cell cycle arrest is achieved through distinct cell-specific transcriptional regulatory mechanisms. Molecular Cell Biology 17 3181-3193.

Rüdiger JJ, Roth M, Bihl MP, Cornelius BC, Johnson M, Ziesche R \& Block LH 2002 Interaction of C/EBPalpha and the glucocorticoid receptor in vivo and in nontransformed human cells. FASEB Joumal 16 177-184.

Samuelsson MK, Pazirandeh A, Davani B \& Okret S 1999 p57 Kip2, a glucocorticoid-induced inhibitor of cell cycle progression in HeLa cells. Molecular Endocrinology 13 1811-1822.

Sanchez I, Goya L, Vallerga AK \& Firestone GL 1993 Glucocorticoids reversibly arrest rat hepatoma cell growth by inducing an early G1 block in cell cycle progression. Cell Growth Differentiation 4 215-225.

Schulz M, Eggert M, Baniahmad A, Dostert A, Heinzel T \& Renkawitz R 2002 RU486-induced glucocorticoid receptor agonism is controlled by the receptor $\mathrm{N}$ terminus and by corepressor binding. Fournal of Biological Chemistry 277 26238-26243.

Sherr CJ 1993 Mammalian G1 cyclins. Cell 73 1059-1065.

Sherr CJ \& Roberts JM 1999 CDK inhibitors: positive and negative regulators of G1-phase progression. Genes and Development 13 $1501-1512$

Stocklin E, Wissler M, Gouilleux F \& Groner B 1996 Functional interactions between Stat5 and the glucocorticoid receptor. Nature $383726-728$.

Subramaniam N, Campion J, Rafter I \& Okret S 2003 Cross-talk between glucocorticoid and retinoic acid signals involving glucocorticoid receptor interaction with the homeodomain protein Pbxl. Biochemical fournal 370 1087-1095.

Teurich S \& Angel P 1995 The glucocorticoid receptor synergizes with Jun homodimers to activate AP-1-regulated promoters lacking GR binding sites. Chemical Senses 20 251-255.

Zilliacus J, Wright AP, Carlstedt-Duke J \& Gustafsson JA 1995 Structural determinants of DNA-binding specificity by steroid receptors. Molecular Endocrinology 9 389-400.

Received in final form 14 February 2003 Accepted 19 February 2003 